удк 347.7

DOI https://doi.org/10.32837/pyuv.v0i4.618

\author{
I. Ю. Гришко \\ orcid.org/0000-0003-4885-4040 \\ магістрантка \\ Сулського державного університету
}

Навчально-наукового інституту права

М. С. Уткіна

orcid.org/0000-0002-3801-3742

кандидат юридичних наук,

старший викладач

кафедри кримінально-правових дисииплін та судочинства

Навчально-наукового інституту права

Сулського державного університету

\title{
ПРОБЛЕМИ ЗАХИСТУ ПРАВ ІНТЕЛЕКТУАЛЬНОЇ ВЛАСНОСТІ В УКРАЇНІ
}

У наш час інтелектуальна діяльність людини, безумовно, має велику цінність і потребує всебічного правового регулювання з метою впорядкування суспільних відносин, які виникають у процесі діяльності людини, що супроводжується інтелектуальними здібностями. Результат такої діяльності обов'язково стає особистим немайновим правом особи, яке охороняється, гарантується, забезпечується та захищається державою. Такий захист зумовлюється прийняттям нормативно-правових актів, які встановлюють обов'язкові правила поведінки, дотримуватися яких мають усі фізичні та юридичні особи. Безперечно, такий захист не обмежується лише нормативним регулюванням, адже важливим $\epsilon$ ефективний механізм реалізації правових норм на практиці з тим, щоб права, свободи та законні інтереси осіб не були порушені. Особливо актуалізується питання захисту прав інтелектуальної власності у цифровому середовищі, що є надзвичайно дискусійним положенням, адже в нашій країні відсутній належний механізм захисту прав на результат інтелектуальної діяльності у глобальній мережі.

Дослідженню окремих аспектів захисту прав інтелектуальної власності присвячено праці таких вчених-правників, як А. Безмолитвенного, I. Василенка, В. Дроб'язко, В. Жарова, З. Пічкурової, Доріс Лонг та інші. У правовій доктрині захист прав інтелектуальної власності був предметом розгляду багатьох представників наукової спільноти, а тому їх внесок у дослідження механізму захисту прав інтелектуальної власності є значним. Проте вважаємо за доцільне систематизувати та визначити ряд актуальних сьогодні проблемних моментів, що супроводжують процес захисту інтелектуальної власності, а також запропоновувати можливі напрями їх вирішення. Метою статті є правове дослідження поняття «інтелектуальна власність», юридична характеристика способів захисту права інтелектуальної власності, а також дослідження проблемних питань у вказаній сфері та ймовірних шляхів їх вирішення.

Насамперед необхідно проаналізувати правову природу дефініції «інтелектуальна власність». Нормативно цей термін закріплено на міжнародному рівні у Конвенції про заснування Всесвітньої організації інтелектуальної власності. Відповідно до ст. 2: «інтелектуальна власність» містить права, що належать до: літературних, художніх і наукових творів; виконавчої діяльності артистів, звукозапису, радіо- і телепередач; винаходів у всіх сферах діяльності людини; наукових винаходів; промислових зразків; торговельних марок, фірмових найменувань і комерційних позначень; захисту від недобросовісної конкуренції, а також всі інші права, які є результатом інтелектуальної діяльності в промисловій, науковій, літературній та художній сферах [1]. Аналізуючи визначення поняття, запропоноване в Конвенції, зазначимо, що вона не регламентує саме поняття інтелектуальної власності, натомість містить перелік прав особи, які позначають право інтелектуальної власності, тобто є результатом інтелектуальної діяльності людини у різних сферах суспільного життя.

Вітчизняне законодавство, а саме Конституція України, у ст. 41 закріплює право кожного володіти, користуватися і розпоряджатися своєю власністю, результатами своєї інтелектуальної, творчої діяльності. Отже, забороняється використання та поширення без згоди особи результатів iii інтелектуальної діяльності [2]. Цивільний кодекс України у ст. 418 визначає поняття «право інтелектуальної власності» як «право особи на результат інтелектуальної, творчої діяльності або на інший об'єкт права інтелектуальної власності, визначений законодавством. Право інтелектуальної власності становлять особисті немайнові права інтелектуальної власності та (або) майнові права ін- 
телектуальної власності, зміст яких щодо певних об’єктів права інтелектуальної власності визначається Цивільним кодексом та іншим законом» [3]. На нашу думку, потрібно закцентувати увагу на важливому аспекті права інтелектуальної власності: співвідношенні права власності та права інтелектуальної власності. Так, ст. 419 Цивільного кодексу України вказує на незалежність права інтелектуальної власності від права власності на річ. Перехід права на об’єкт права інтелектуальної власності не означає перехід права власності на річ, а також, відповідно, перехід права власності на річ не означає переходу права на об'єкт права інтелектуальної власності. Отже, законодавчо суб'єктивне право особи на об'єкт інтелектуальної власності та речове право на матеріальний об'єкт чітко розмежовуються. Наприклад, художник як власник права інтелектуальної власності на твір образотворчого мистецтва залишиться власником цього права навіть у результаті переходу речового права власності на матеріальний об’єкт (картину, в якій виражене право інтелектуальної власності) до іншої особи. Тобто така особа придбає лише картину, але не право інтелектуальної власності на твір, зображений на ній.

Аналізуючи доктринальні підходи до розуміння права інтелектуальної власності, зазначимо, що, на думку 3.В. Пічкурової, «... інтелектуальна власність являє собою сукупність відносин щодо володіння, користування та розпорядження результатами інтелектуальної діяльності людини в галузі науки, технологій, літературно-мистецької діяльності...» [4, с. 216]. Доріс Лонг та інші визначають інтелектуальну власність як формалізований результат творчої, інтелектуальної діяльності, що надає його автору або особі, визначеній чинним законодавством, право власності на цей результат, яке набувається, здійснюється та захищається відповідно до законодавчо встановлених норм і правил [5, с. 105]. На нашу думку, право інтелектуальної власності доцільно визначити як суб'єктивне, непорушне, гарантоване державою право особи володіти, користуватися та розпоряджатися об’єктом, що є результатом інтелектуальної діяльності, вимагати недопущення порушень такого права з боку інших осіб, а також охорони та захисту об'єкта від неправомірних посягань.

Право інтелектуальної власності потребує захисту з боку держави від неправомірних посягань. На нашу думку, захист права інтелектуальної власності слід розглядати як систему заходів правового та організаційного характеру, спрямованих на створення належних умов для вільного володіння, використання та розпорядженням об'єктом, що є результатом інтелектуальної діяльності особи. Особливої актуальності це питання набуває під час бурхливого розвитку інформаційно-телекомунікаційних технологій, що дає не лише змогу вільно, безперешкодно та на свій розсуд використовувати різний контент, але й зловживати таким правом в напряму порушень інтелектуальної власності особи.

Захист права інтелектуальної власності здійснюється у двох основних формах: юрисдикційній та неюрисдикційній. Перша передбачає діяльність уповноважених державою органів щодо захисту порушених прав на об'єкти інтелектуальної власності або прав, що оспорюються. Найефективнішою юрисдикційною формою захисту права інтелектуальної власності є судовий захист. Щодо другої форми захисту прав, то вона включає дії юридичних і фізичних осіб щодо захисту прав на об'єкти інтелектуальної власності, які здійснюються ними самостійно, без звернення за допомогою до державних або інших компетентних органів. Переважною формою неюрисдикційного захисту є самозахист, що проявляється в активних чи пасивних діях особи, спрямованих на запобігання чи припинення порушення власного суб'єктивного права [6, с. 207]. Зокрема, відповідно до статті 432 Цивільного кодексу суд під час розгляду справи про порушення прав інтелектуальної власності може постановити такі рішення: про застосування негайних заходів щодо запобігання порушенню права інтелектуальної власності та збереження відповідних доказів; про зупинення пропуску через митний кордон України товарів, імпорт чи експорт яких здійснюється з порушенням права інтелектуальної власності; про вилучення 3 цивільного обороту товарів, виготовлених або введених у цивільний оборот з порушенням права інтелектуальної власності та знищення таких товарів; про вилучення з цивільного обороту матеріалів та знарядь, які використовувалися переважно для виготовлення товарів з порушенням права інтелектуальної власності або вилучення та знищення таких матеріалів та знарядь; про застосування разового грошового стягнення замість відшкодування збитків за неправомірне використання об’єкта права інтелектуальної власності [3].

Окремо слід зосередити увагу на такому способі захисту прав інтелектуальної власності, як судова заборона, яка полягає в забороні дій, що порушують право особи чи створюють загрозу для його порушення. Рішення про попередню заборону повинно бути винесене після того, як власник прав інтелектуальної власності доведе за допомогою доступних йому доказів і 3 «достатнім ступенем достовірності», що порушення його прав $€$ «невідворотним». Має існувати можливість прийняття рішень про попередню заборону на здійснення неправомірних дій в процесі судового розгляду. Це правило закріплене також у статтях 52 , 52-1, 52-2 Закону «Про авторське право і суміжні права». Особливо актуальним є питання судової заборони у разі порушення авторських прав 3 
використанням мережі Інтернет [5, с. 46]. Судова заборона у справах щодо захисту авторського права на розміщені в мережі Інтернет твори може полягати, наприклад, у видаленні твору зі змісту веб-сторінки або у веб-блокуванні. Так, у положеннях ст. 12-14 Директиви 2000/31/ЄС «Про деякі правові аспекти інформаційних послуг, зокрема електронної комерції, на внутрішньому ринку» [7] і ст. 245-247 Угоди про асоціацію з ЄС [8] прямо зазначається, що випадки обмеження відповідальності постачальників посередницьких послуг (просто посередник, хостинг, кешування) не впливають на можливість для судового або адміністративного органу, відповідно до правових систем Сторін, вимагати від постачальника послуг припинити або попередити порушення.

Адміністративний спосіб захисту полягає в розгляді та вирішенні суперечки органом державного управління або судом. Адміністративний спосіб захисту прав передбачено за порушення прав на об'єкт права інтелектуальної власності, демонстрування і розповсюдження фільмів без державного посвідчення на право розповсюдження і демонстрування фільмів, незаконне розповсюдження примірників аудіовізуальних творів, фонограм, відеограм, комп'ютерних програм, баз даних [9]. Зокрема, порушення прав на об’єкт права інтелектуальної власності тягне за собою відповідальність у вигляді штрафу від десяти до двохсот неоподатковуваних мінімумів доходів громадян з конфіскацією незаконно виготовленої продукції та обладнання і матеріалів, які призначені для її виготовлення.

Потрібно зазначити, що способи захисту прав інтелектуальної власності в Україні фактично не $€$ достатньо дієвими та ефективними. Такі висновки доцільно зробити з огляду на показник індексу прав власності в Україні. Міжнародний індекс прав власності (IPRI), єдиний у світі індекс, повністю присвячений вимірюванню прав інтелектуальної та фізичної власності, котрий відображає результати досліджень Property Rights Alliance в сферах правового та політичного середовища, права фізичної власності та права інтелектуальної власності. Індекс прав власності демонструє, зокрема, рівень захисту прав інтелектуальної власності в країні [10]. Порівнюючи індекс України та провідних європейських держав, слід зазначити, що індекс нашої країни є нижчим, порівняно з Фінляндією, Німеччиною та Польщею. Досліджуючи динаміку України за показником індексу прав власності, слід констатувати, що протягом 2018-2019 років індекс дещо зрушився з місця та підвищився, проте рух цього показника є достатньо повільним.

До того ж, згідно з річною доповіддю Єврокомісії щодо захисту та забезпечення прав інтелектуальної власності у третіх країнах, Індія, Індо- незія, Росія, Туреччина і Україна залишаються країнами 2-го пріоритету. У цих країнах виявили серйозні системні проблеми у сфері захисту та дотримання прав інтелектуальної власності, що спричиняє суттєву шкоду бізнесу Євросоюзу. У порівнянні з попередньою доповіддю ці країни не мали прогресу або продемонстрували лише обмежений прогрес у вирішенні цих занепокоєнь.

Серед проблемних питань захисту прав інтелектуальної власності в Україні слід виділити такі:

- невідповідність окремих положень чинного законодавства України європейським стандартам у сфері захисту інтелектуальної власності;

- відсутність окремого спеціалізованого судового органу з розгляду справ щодо порушення інтелектуальної власності;

- складність збору доказової бази для доведення факту порушення права інтелектуальної власності в суді;

- організаційно-правові недоліки процедури захисту прав інтелектуальної власності в судовому порядку.

Існує цілий ряд міжнародних договорів, що регулюють відносини в сфері інтелектуальної власності на міжнародному рівні. Євроінтеграційний курс України свідчить про її бажання адаптувати свою правову систему до європейських стандартів, а тому, укладаючи Угоду про асоціацію з СС, Україна взяла на себе зобов'язання гармонізувати своє законодавство у сфері інтелектуальної власності 3 європейським законодавством. Угода містить положення директив та регламентів СС щодо різних аспектів охорони прав інтелектуальної власності: авторських прав, географічних зазначень, торговельних марок тощо [8]. Через відмінність окремих положень вітчизняного законодавства від норм європейських директив та регламентів місце мають колізії, що призводить до відмінних судових рішень з однотипних питань.

Як справедливо наголошує К. Зеров, судові заборони у вигляді веб-блокування не повинні використовуватися як засоби загального блокування інформації в Інтернеті, оскільки в такому разі вони можуть порушувати право на свободу вираження поглядів, гарантоване ст. 10 Конвенції про захист прав людини і основоположних свобод [11, с. 86]. Вважаємо за доцільне доповнити Закон "Про авторське право і суміжні права» нормою про можливість накладення судової заборони на провайдера (постачальника послуг), що підвищить ефективність механізму захисту прав інтелектуальної власності.

Одним із проблемних питань захисту прав інтелектуальної власності є складність збору доказової бази для доведення факту порушення права інтелектуальної власності в суді. Зокрема, факт порушення права інтелектуальної власності дуже 
складно довести в суді. Наприклад, рішенням Деснянського районного суду м. Києва у справі № 754/7539/16-ц від 31.01. 2017 р. позивачці відмовлено у задоволенні позову про захист авторських прав щодо розповсюдження контрафактних схем для вишивання бісером відповідачкою, в яких без дозволу втілено твори образотворчого мистецтва позивачки. Суд зазначив: «Будь-яких конкретних правових доказів, які б свідчили про порушення відповідачем по відношенню до позивачки їі авторського права і (або) суміжних прав, що дає підстави для судового захисту, шляхом піратства у сфері авторського права і (або) суміжних прав - опублікування, відтворення, ввезення на митну територію України, вивезення з митної території України і розповсюдження контрафактних примірників творів <...> позивачка зі своїм представником суду не надали, і судом таких доказів не здобуто. 3 доданих до позову в обгрунтування позовних вимог, копій творів не вбачається, що вони розповсюджувались відповідачем» [12].

Авторське право не вимагає обов'язкової державної реєстрації чи будь-якого іншого спеціального оформлення. При цьому свідоцтво, видане Міністерством розвитку економіки, торгівлі та сільського господарства України, є найбільш значущим доказом приналежності авторських прав, а також дата створення твору. Для позначення авторського права в публікаціях використовується знак охорони авторського права, після якого вказується ім'я автора та рік публікації твору. 3 метою захисту права інтелектуальної власності своє авторське право доцільно реєструвати у встановленому законодавством порядку, що буде належним та безспірним доказом права в суді.

Істотним недоліком механізму захисту прав інтелектуальної власності в Україні є відсутність спеціалізованого судового органу, покликаного розглядати справи про правопорушення у сфері інтелектуальної власності. Позитивним є досвід європейських країн, де діють такі установи, зокрема Німеччини, Великобританії та інших країн. Формально, в Україні такий орган є, адже згідно з Указом Президента України від 29 вересня 2017 року «Про утворення Вищого суду з питань інтелектуальної власності» така судова установа утворена, проте на практиці досі не функціонує. Побудова судів за принципом спеціалізації $\mathrm{e}$ ефективним способом організації судової системи. Функціонування такого суду де-факто сприяло б підвищенню рівня захисту прав інтелектуальної власності в Україні, адже суддями такого суду мають бути особи, які володіють спеціальними знаннями у сфері інтелектуальної власності, мають практичний досвід вирішення суперечок в інтелектуальній сфері, встановленню єдиного підходу до вирішення спорів, завдяки аналізу судової статистики Вищим судом з питань інтелектуальної власності, оперативності розгляду справ з огляду на безпосередню зосередженість суддів виключно на справах, пов'язаних з порушенням прав інтелектуальної власності.

Для України характерною є практика «затягування» судових справ. Для цього наразі є всі підстави, адже у разі помилки з підвідомчістю, сторона справи може звернутися з відповідним клопотанням до суду, і справа, яка перебуває на розгляді у касаційній інстанції, може повернутися до суду першої інстанції, тобто має місце реальне «гальмування» справ. В Україні такі судові спори можуть тривати від 2 до 5 років. Наприклад, строки розгляду справ патентними судами іноземних держав складають в середньому рік. Так, Патентний суд Великобританії зазвичай розглядає подібні справи за 12-14 місяців, Федеральний патентний суд Швейцарії та Суд 3 інтелектуальних прав РФ - за 12 місяців, Федеральний патентний суд Німеччини - максимум за 18 місяців» [13].

Україна є країною транзиту підробленої та піратської продукції в таких секторах, як харчова промисловість, годинники, ювелірні прикраси, іграшки, одяг, фотографічне та медичне обладнання. Деякі піратські сайти, які пропонують таку продукцію, відкрито діють в Україні, кількість таких сайтів навіть збільшується, що пояснюється недосконалістю та слабкістю чинного законодавства. На нашу думку, вирішувати такі проблемні питання доцільно шляхом удосконалення законодавчої бази, в тому числі посилення юридичної відповідальності за порушення у сфері інтелектуальної власності, зокрема щодо розповсюдження піратської продукції. Крім цього, потрібно удосконалити механізм виявлення таких правопорушень, розширити права правоохоронних органів у напряму надання додаткових організаційно-правових механізмів виявлення та протидії порушенням права інтелектуальної власності.

3 огляду на вищевикладене робимо висновки, що натепер в Україні рівень захисту прав інтелектуальної власності не є достатньо високим та ефективним. Труднощі виникають з огляду на різні чинники, проте головною проблемою, на наш погляд, є недосконалість правового регулювання, а також практичні аспекти. Зокрема, відсутність спеціалізованого суду (його функціонування), складність доведення факту порушення права інтелектуальної власності тощо. Тому вважаємо, що реформування законодавства, удосконалення механізму судового захисту інтелектуальної власності, імплементація європейського законодавства призведе до формування належного рівня захисту права інтелектуальної власності в Україні. 


\section{Iimepamypa}

1. Конвенція про заснування Всесвітньої організації інтелектуальної власності: Конвенція від 14.07.1967. URL: https://zakon.rada.gov.ua/laws/ show/995 169\#Text.

2. Конституція України : Закон України від 28.06.1996 p. № 254к/96-ВР.

3. Цивільний кодекс України : Закон України від 16.01.2003 р. № 435-IV

4. Пічкурова 3. Систематизація теоретичних положень та наукових поглядів на економічний зміст інтелектуальної власності. Наукові записки Націо нального університету «Острозька акаделія». Серія «Еконоліка». 2013. Вип. 24. С. 215-219

5. Доріс Лонг, Патриція Рей, Жаров В. та ін. Захист прав інтелектуальної власності: норми міжнародного і національного законодавства та їх правозастосування : практичний посібник. Київ : «К.І.С.», 2007. 448 с.

6. Юлдашев О. Міжнародне приватне право: теоретичні та прикладні аспекти. Київ : МАУП, 2004. 576 с.

7. Директива 2000/31/ЄC Європейського парламенту та Ради «Про деякі правові аспекти інформаційних послуг, зокрема, електронної комерції, на внутрішньому [...]: міжнародний документ від 08.06.2000 № 2000/31/CC. URL: https://zakon.rada.gov.ua/laws/ show/994 224\#Text

8. Угода про асоціацію між Україною, з однієї сторони, та Європейським Союзом, Свропейським співтовариством з атомної енергії і їхніми державами-членами, зіншої [...]: міжнародний документ від 27.06.2014. URL: https://zakon.rada.gov.ua/laws/show/984_011\#Text.

9. Кодекс України про адміністративні правопорушення (статті 1 - 212-24): Кодекс України; Закон, Кодекс від 07.12.1984 № 8073-Х.

10. Міжнародний індекс прав власності. URL: https://ueff.org/uk/indeksy/77-property-rightsalliance-indeks-prav-vlasnosti.

11. Зеров К. Веб-блокування як спосіб захисту авторських прав на твори, що розміщені в мережі Інтернет. Законодавство України у сфері інтелектуальної влас ності та його правозастосування: збірник наукових праць IV Всеукраїнської науково-практичної конференції (м. Київ, 23.09.2016 року). Київ, 2016. С. 84-93.

12. Рішення Деснянського районного суду м. Києва у справі №754/7539/16-ц від 31 січня 2017. $є \partial u-$ ний державний реєстр судових рішень: веб-сайт. URL: http://www.reyestr.court.gov.ua/Review/64494769.

13. Пашковська Т. Вищий «інтелектуальний» суд: на фінішній прямій. Протокол. Юридичний інтернет-ресурс. URL: https://protocol.ua/ua/vishchiy_ intelektualniy_sud_na_finishniy_pryamiy/.

\section{Анотація}

Гришко І. Ю., Уткіна М.С. Проблеми захисту прав інтелектуальної власності в Україні. - Стаття.

У статті охарактеризовано доктринальні та нормативні підходи до визначення поняття «право інтелектуальної власності»; проаналізовано співвідношення права власності та права інтелектуальної власності та запропоновано дефініцію праваінтелектуальноївласності. Досліджено поняття «захист права інтелектуальної власності» та запропоновано його визначення. Охарактеризовано юрисдикційну та неюрисдикційну форми захисту права інтелектуальної власності, з'ясовані основні способи захисту права інтелектуальної власності. Акцентовано увагу на судовій забороні як способі захисту права інтелектуальної власності, проаналізовано міжнародний індекс прав власності, зокрема рівень захисту прав інтелектуальної власності в Україні. Здійснено порівняння індексу прав власності в Україні та провідних європейських державах, встановлено факт низького показника захисту прав інтелектуальної власності в нашій державі порівняно $з$ європейськими країнами. Досліджено динаміку України у сфеpi захисту прав інтелектуальної власності протягом 2015-2019 років та виділено основні проблемні питання захисту права інтелектуальної власності в Україні. Наголошено на необхідності адаптації національного законодавства до правової системи Європейського союзу. Наведено положення ряду європейських нормативно-правових актів, які регламентують питання захисту права інтелектуальної власності. Охарактеризована проблематика збору доказової бази щодо порушення права інтелектуальної власності, проаналізовано національну судову практику з цього питання. Наголошено на необхідності створення спеціалізованого судового органу, який би розглядав справи про порушення прав інтелектуальної власності. Запропоновано законодавчо уточнити вимоги до кандидатів на посаду судді Вищого суду з питань інтелектуальної власності, акцентовано увагу на необхідності посилення юридичної відповідальності за порушення у сфері інтелектуальної власності, зокрема щодо розповсюдження піратської продукції. Окреслено організаційно-правові недоліки процедури захисту прав інтелектуальної власності, запропоновано ряд способів, які допоможуть вирішити проблемизахиступравінтелектуальноївласностівУкраїні.

Ключові слова: право інтелектуальної власності, захист права інтелектуальної власності, способи захисту права інтелектуальної власності.

\section{Summary}

Hryshko I. Yu., Utkina M. S. Problems of intellectual property rights protection in Ukraine. - Article.

The article describes the doctrinal and normative approaches to the definition of intellectual property rights, analyzes the relationship between property rights and intellectual property rights, proposes a definition of intellectual property rights, explores the concept of protection of intellectual property rights and offers its definition, describes jurisdictional and non-legal forms of jurisdiction, the main ways of protection of intellectual property rights are clarified, attention is paid to court injunction as a way of protection of intellectual property rights, the international index of property rights is analyzed, in particular the level of protection of intellectual property rights in Ukraine. the fact of low rate of protection of intellectual property rights in our country compared to European Cains, the dynamics of Ukraine in the field of protection of intellectual property rights against 2015-2019, highlighted the main issues of protection of intellectual property rights in Ukraine, stressed the need to adapt national legislation to the legal system of the European Union, the provisions of a number of European regulations governing the protection of intellectual property rights, described the collection of evidence bases on infringement of intellectual property rights, analyzed national case law on this issue, stressed the need to create a specialized judicial body that would consider cases of infringement of intellectual property rights, proposed to clarify the requirements for candidates for judge of the Supreme Court on intellectual property, attention to the need to strengthen legal liability for infringements in the field of intellectual property, in particular, the distribution of pirated products, outlined the organizational and legal shortcomings of the procedure for protection of rights intellectual property, proposed a number of ways to help solve the problem of protection of intellectual property rights in Ukraine.

Key words: intellectual property law, protection of intellectual property rights, ways of protection of intellectual property rights. 